\title{
Journal
}

Peqguruang: Conference Series

JPCS

elSSN: 2686-3472

Vol. 2 No. 1 Mei 2020

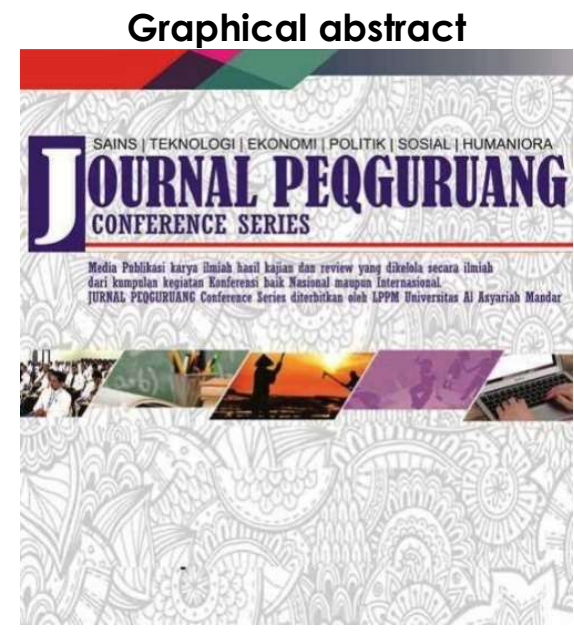

\section{FAKTOR YANG BERHUBUNGAN DENGAN PENGGUNAAN JAMBAN DI RUANG POLI KLINIK RUMAH SAKIT UMUM DAERAH POLEWALI MANDAR KABUPATEN POLEWALI MANDAR}

${ }^{1 *}$ Dinda Novitasari, ${ }^{1}$ Urwatil Wusqa Abidin, ${ }^{1}$ Andi Liliandriani, ${ }^{1}$ Sri Nengsi

${ }_{1}$ Universitas Al Asyariah Mandar

*Corresponding author

dindanovitasari23@yahoo.com

\begin{abstract}
Toliets are the most important part the human enviroment, latrines that do not meet the standards of the national health agency can be a source of various diseases due to environmental pollution from feces. The purpose of this study was to determine the relationship factors of knowledge, latrine construction, latrine hygiene, and the availability of clean water with the use of latrines in the Poli Clinic Room of the Polewali Mandar Regional General Hospital in 2020. This type of research uses an observational type with a cross sectional study approach. The results showed that there was a correlation between knowledge factors and the use of latrines in the Poli Clinic Room at Polewali Mandar Regional General Hospital where the $\mathrm{P}$ value was $0.01<0.05$, there was a correlation between latrine construction factor and latrine where the $\mathrm{P}$ value is $0.040<0.05$, there is a relationship between latrine sanitation factors and the use of latrines where the $\mathrm{P}$ value is $0.029<0.05$. And there is a correlation between the availability of clean water and the use of latrines in the Poli Clinic Room at the Polewali Mandar Regional General Hospital where the $\mathrm{P}$ value is $0.002<0.05$.
\end{abstract}

Keywords: Latrines, Hospital, Factors, Relationships

\section{Abstrak}

Jamban merupakan bagian terpenting dalam lingkungan manusia, jamban yang tidak sesuai standar badan kesehatan nasional dapat menjadi sumber datangya berbagai penyakit akibat pencemaran lingkungan dari tinja. Penelitian ini bertujuan untuk mengetahui faktor hubungan pengetahuan, kontruksi jamban, kebersihan jamban, dan ketersediaan air bersih dengan penggunaan jamban di Ruang Poli Klinik Rumah Sakit Umum Daerah Polewali Mandar Tahun 2020. Penelitian ini menngunakan jenis penelitian observasional sedangkan pendekatan penelitiannya menggunakan Cross Sectional Study yaitu mengetahui faktor yang Berhubungan dengan Penggunaan Jamban di Ruang Poliklinik UmumRumah Sakit Umum Daerah Polewali Mandar yang diamati pada priode yang sama. Hasil pada penelitian ini menunjukkan dimana ada hubungan faktor pengetahun dengan penggunaan jamban di Ruang Poli Klinik Rumah Sakit Umum Daerah Polewali Mandar dimana nilai P 0,01< 0,05, Ada Hubungan Faktor Kontruksi Jamban dengan Penggunaan Jamban dimana nilai $\mathrm{P} 0,040<0,05$, Ada Hubungan Faktor Sanitasi Jamban dengan Penggunaan Jamban dimana nilai $\mathrm{P} 0,029<0,05$. Serta Ada Hubungan Faktor Ketersediaan Air Bersih dengan Penggunaan Jamban di Ruang Poli klinik Rumah Sakit Umum Daerah Polewali Mandar dimana nilai p $0,002<0.05$.

Kata kunci: Jamban, Rumah Sakit, Faktor, Hubungan 


\section{PENDAHULUAN}

Menurut Moelok (2016) pada tahun 2015 hingga 2019 Program Indonesia sehat membentuk sebuah program prioritas kesehatan demi mewujudkan pandangan yang sehat, menguatkan berbagai pelayanan dan jaminan secara nasional. Program indonesia yang sehat adalah salah satu bagian dari agenda nawa cita, dimana yaitu demi peningkatan kualitas kehidupan manusia. Melalui rencana startegis yang tertuang dalam ketentuan menteri kesehatan R.I. Nomor HK.02.02/Menkes/52/2015 terkait program indonesia sehat menjadi program utama dalam pembangunan kesehatan.

Menurut Moelok (2012) Terdapat 12 indikator yang tertuang dalam Pembangunan Indonesia Sehat yang mana dijadikan penanda untuk status kesehatan keluarga. Dalam indicator tersebut salah satu diantaranya yang cukup utama adalah memiliki akses sanitasi yang layak dalam hal ini penggunaan dan pemanfaatan jamban. Di Indonesia masih berada di status yang cukup besar terkait masalah sanitasi lingkungan. Hal ini sesuai dengan data yang dikeluarkan organisasi kesehatan dunia yaitu WHO bahwa tahun 2015 ada $68 \%$ persen dampak buruk dari sanitasi yang tidak bersih dan mengalami pencemaran berat serta ada sekitar $13 \%$ penduduk di dunia yang sampai saat ini membuang tinja di ruang yang tidak seharusnya atau terbuka. Tempat umum atau sarana umum yang dikelola secara komersial, tempat yang memfasilitasi terjadinya penularan penyakit, atau tempat layanan umum yang intensitas jumlah dan waktu kunjungan tinggi (Rahma, A. S. N., Sukmawati, S., \& Liliandriani, A. 2019).

Kesehatan adalah bagian dari fenomena sosial, oleh karena itu dapat disadari bahwa pelayanan dari kesehatan bukan satu-satunya faktor penyebab yang mempengaruhi kesehatan masyarakat namun juga disertai oleh lingkungan dan perilaku dari manusia itu sendiri yang pengaruhnya jauh lebih besar dibanding pelayanan Masyarakat. Salah satu faktor ingkungan yang cukup berpengaruh adalah ketersediaan air bersih dan kebiasaan Masyarakat membuang tinja disembarang tempat.

Data yang dikeluarkan BPS tahun 2010 dimana tercatat tahun 2015 penduduk indonesia sekitar 248 jiwa. Dimana dari populasi tersebut menunjukkan masih ada 110 jiwa yang tinggal atau bermukim di perkotaan tetapi sanitasinya belum memenuhi standar kesehatan. Serta juga ada 55 juta jiwa belum memiliki akses terhadap air minum serta diperkirakan masih ada 153juta jiwa di pedesaan yang belum memiliki akses sanitasi yang baik dan 77 juta jiwa yang tidak memiliki akses terhadap air minum (Riskedas, 2010).

Akses sanitasi adalah hal yang cukup penting sebab merupakan salah satu penyebab uama timbulnya berbagai penyakit seperti penyakit diare, disentri, korela hipetitis dan lain-lain (Kemenkes, RI, 2016). Dari data Dirjen P2P (2016) menemukan penemuan kasus diare yang tergolong tinggi dimana sebesar 36,9\%, hal ini masih jauh dari target yang diharapkan dimana dibawah
1\%. Ada banyak cara untuk untuk mencegah berkembangnya berbagai penyakit serta menjaga lingkungan sehat yaitu dengan melalui diantaranya membangung jamban di rumah serta dan juga memastikan jamban yang dipakai sesuai standar yang ditetapkan atau memenuhi syarat. Hal ini dikarekana jamban adalah kebutuhan utama dan penting bagi manusia. Oleh karena itu diharapkan setia orang atau individu untuk bisa memanfaatkan jamban dalm buang tinja atau air besar. Pernyataan ini senada yang diungkapkan Almsyah dan Muliawati (2013) bahwa Penggunaan jamban memiliki manaaf yang besar dalam menajag kesehatan, kebersihan dan kenyamanan lingkungan dimana kita tinggal. Syarat kondisi jamban yang sehat diantaranya air cukup, air tidak tergenang dan memepunyai air bersih yang cukup untuk sanitasi jamban. Hasil observasi menunjukkan bahwa jamban/WC cukup tersedia, kondisi lantai sangat kaut, tidak licin, kedap air. Persediaan air rumah sakit bersumber dari sumur bor dan air pam.

Sebagai upaya membangun budaya hidup yang bersih, sehat dan mencegah untuk tersebarnya berbagai penyakit yang ditimbulkan pencemaran lingkungan, meningkatkan kemampuan masyarakat sekaligus membantu pemerintah dalam meningkatkan akses air yang layak dan sanitasi dasar yang terkoneksi dan berkesinambungan dalam mencapai MDGs tahun 2015. Maka dari itu dianggap perlu menyusun strategi nasional yang berbasis masyarakat ditetapkan dengan Keputusan Menteri Kesehatan (MENKES, 2008)

Berdasarkan hasil observasi yang dilakukan di RS Umum Polewali Mandar bahwa masih banyak pengunjung yang mengeluhkan keadaan jamban di Rumah Sakit tersebut, Seperti ada air kerang yang airnya tidak berjalan baik, dan sanitasi jamban yang kadang tidak diberishkan serta fasilitas yang ada. Berangkat dari data penemuan tersebut penulis tertarik untuk melakukan penelitian di Ruang Poli Klinik RS Umum Polewali Mandar untuk mengetahui faktor yang berhubungan dengan penggunaan jamban di Ruang Poli Klinik RS Umum Polewali Mandar

\section{METODE PENELITIAN}

Penelitian ini menngunakan jenis penelitian observasional sedangkan pendekatan penelitiannya menggunakan Cross Sectional Study yaitu mengetahui faktor yang Berhubungan dengan Penggunaan Jamban di Ruang Poliklinik UmumRumah Sakit Umum Daerah Polewali Mandar yang diamati pada priode yang sama. Dalam penelitian ini populasi yang digunakan adalah pengguna jamban yang ada di Ruang Poli Klinik Rumah Sakit Umum Daerah Polewali Mandar sedangkan sampel dari perhitugan rumus slovin sebanyak 97 orang. Karena penelitian ini mencari hubungan, maka jenis penelitian menggunakan analisi Univariat dan Bivariat dimana metodenya chi squere. 


\section{HASIL DAN PEMBAHASAN}

a. Karakteristik Responden

1) Jenis Kelamin

Dalam penelitian ini Penulis memberikan kuesioner pada pengunjung rumah sakit tanpa membedakan jenis kelamin dalam penelitian demi mendapatkan data yang akurat sesuai dengan kondisi responden. Data yang pertama yaitu jenis kelamin responden, dimana hal ini dilakukan untuk mendapatkan gambaran soal jumlah pria dan wanita yang menjadi objek penelitian. Berikut ini uraian lengkapnya pada tabel 4.1:

Tabel 4.1 Berdasarkan Jenis Kelamin Responden

\begin{tabular}{|c|c|c|c|}
\hline \multirow{2}{*}{ No. } & \multirow{2}{*}{$\begin{array}{c}\text { Jenis } \\
\text { kelamin }\end{array}$} & \multicolumn{2}{|c|}{ Jumlah } \\
\cline { 3 - 4 } & & $\begin{array}{c}\text { Sampel } \\
\text { (n) }\end{array}$ & $\begin{array}{c}\text { Presentas } \\
\text { e (\%) }\end{array}$ \\
\hline 1 & Pria & 47 & $49,6 \%$ \\
2 & Wanita & 50 & $51,4 \%$ \\
\hline & Total & 97 & 100 \\
\hline
\end{tabular}

Sumber: Data yang diolah 2020

Dari tabel diatas menunjukan presentase Jumlah reponden pria yang mengisi kuesioner lebih sedikit dari wanita. Terlihat ada sebanyak 47 ataau $49,6 \%$ responden Pria danjumlah reponden wanita sebanyak 50 atau $51,4 \%$.Hal ini menunjukkan bahwa responden didominasi oleh wanita.

\section{2) Umur}

Usia atau umur adalah usia dari pengunjung ruang poli klinik Rumah Sakit Umum Daerah Polewali Mandar yang diambil sebagai responden. Untuk lebih jelasnya, berikut datanya pada tabel 4.2 :

Tabel 4.2 Persentase dan frekuensi umur responden

\begin{tabular}{|c|c|c|c|}
\hline No. & Usia & \multicolumn{2}{|c|}{ Jumlah } \\
\cline { 3 - 4 } & & $\begin{array}{c}\text { Sampel } \\
\text { (n) }\end{array}$ & $\begin{array}{c}\text { Presentase } \\
(\%)\end{array}$ \\
\hline 1 & $15-25$ & 19 & $19,5 \%$ \\
2 & $25-35$ & 42 & $44,3 \%$ \\
3 & $35-45$ & 22 & $22,6 \%$ \\
4 & $>45$ & 15 & $15,4 \%$ \\
& tahun & & \\
\hline \multicolumn{2}{|c|}{ Total } & 97 & $100 \%$ \\
\hline
\end{tabular}

Sumber: Olah data, 2020

Dari tabe 4.2 di atas terlihat bahwa umur rata-rata responden paling banyak berkisar umur 25-35 tahun dengan jumlah 42orang 44,3\%atau kemudian responden dengan umur terendah yaitu umur 45 tahun keatas sebanyak 15 orang atau $15,4 \%$.

\section{b. Faktor Pengetahuan}

Tabel 4.3 Kategori dan Distribusi Frekuensi Faktor Pengetahuan di Ruang Poli Klinik Rumah Sakit Umum Daerah Polewali Mandar

\begin{tabular}{|c|c|c|c|}
\hline \multirow{2}{*}{ No. } & \multirow{2}{*}{ Pengetahuan } & \multicolumn{2}{|c|}{ Jumlah } \\
\cline { 3 - 4 } & & $\begin{array}{c}\text { Sampel } \\
\text { (n) }\end{array}$ & $\begin{array}{c}\text { Presentase } \\
(\%)\end{array}$ \\
\hline 1 & Baik & 76 & $78,35 \%$ \\
\hline
\end{tabular}

\begin{tabular}{|c|c|c|c|}
\hline 2 & Kurang & 21 & $21,64 \%$ \\
\hline & Total & 97 & 100 \\
\hline
\end{tabular}

Sumber: Data diolah 2020

Pada tabel 4.3 dapat diketahui bahwa antara Pengetahuan baik dan kurang memiliki perbedaan persentase yang cukup jauh dimana baik ada 76 orang atau 78,35\% dan Kurang ada 21 orang atau secara persentase yaitu $21 \%$.

c. Faktor Kontruksi Jamban

Tabel 4.4 Kategori dan Distribusi Frekuensi Kontruksi Jamban

\begin{tabular}{|c|c|c|c|}
\hline No. & Kontruksi & \multicolumn{2}{|c|}{ Jumlah } \\
\cline { 3 - 4 } & Jamban & $\begin{array}{c}\text { Sampel } \\
\text { (n) }\end{array}$ & $\begin{array}{c}\text { Presentase } \\
(\%)\end{array}$ \\
\hline 1 & $\begin{array}{c}\text { Memenuhi } \\
\text { Syarat }\end{array}$ & 77 & $79,3 \%$ \\
& $\begin{array}{c}\text { Tidak } \\
\text { Memenuhi }\end{array}$ & 20 & $20,7 \%$ \\
\hline \multicolumn{2}{|c|}{ Total } & 97 & 100 \\
\hline
\end{tabular}

Sumber: Olah data, 2020

Dari tabe 4.3 di atas terlihat bahwa 77 responden atau $79,3 \%$ yang mengatakan kontruksi jamban memenuhi syarat dan 20 responden yang mengatakan tidak memenuhi syarat atau $20,7 \%$.

d. Faktor Kebersihan Jamban

Tabel 4.5 Kategori dan Distribusi Frekuensi Kebersihan Jamban

\begin{tabular}{|c|c|c|c|}
\hline \multirow[t]{2}{*}{ No. } & \multirow{2}{*}{$\begin{array}{c}\text { Kebersihan } \\
\text { Jamban }\end{array}$} & \multicolumn{2}{|c|}{ Jumlah } \\
\hline & & $\begin{array}{l}\text { Sampel } \\
\text { (n) }\end{array}$ & $\begin{array}{c}\text { Presentase } \\
(\%)\end{array}$ \\
\hline 1 & Bersih & 86 & $88,6 \%$ \\
\hline 2 & $\begin{array}{l}\text { Tidak } \\
\text { Bersih }\end{array}$ & 11 & $11,4 \%$ \\
\hline & Total & 97 & 100 \\
\hline
\end{tabular}

Sumber: Olah data, 2020

Dari tabe 4.4 di atas terlihat bahwa 86 responden atau secara persentase $88,6 \%$ yang mengatakan kebersihan jamban bersih dan sisanya menjawab tidak bersih yaitu 11 responden atau $11,4 \%$.

e. Faktor Ketersediaan Air Bersih

Tabel 4.6 Kategori dan Distribusi Frekuensi Ketersediaan Air Bersih

\begin{tabular}{|c|c|c|c|}
\hline No. & Ketersediaan & \multicolumn{2}{|c|}{ Jumlah } \\
\cline { 3 - 4 } & air bbersih & $\begin{array}{c}\text { Sampel } \\
(\mathrm{n})\end{array}$ & $\begin{array}{c}\text { Presentase } \\
(\%)\end{array}$ \\
\hline 1 & $\begin{array}{c}\text { Memenuhi } \\
\text { Syarat }\end{array}$ & 90 & $92,8 \%$ \\
& $\begin{array}{c}\text { Tidak } \\
\text { Memenuhi }\end{array}$ & 7 & $7,2 \%$ \\
\hline & Total & 97 & 100 \\
\hline
\end{tabular}

Sumber: Olah data, 2020

Dari tabe 4.5 di atas terlihat bahwa 90 responden atau secara persentase $92,8 \%$ yang mengatakan ketersediaan 
air bersih memenuhi syarat dan sisanya menjawab tidak bersih memenuhi syarat yaitu 7 responden atau $7,2 \%$.

1. Analisis Bivariat

a) Hubungan Pengetahuan dan Penggunaan Jamban

Tabel 4.7 Kategori dan Distribusi Frekuensi Hubungan Pengetahuan dengan Penggunaan Jamban di Ruang Poli Klinik Rumah Sakit Umum Daerah Polewali Mandar

\begin{tabular}{|c|c|c|c|c|c|c|c|}
\hline \multirow{2}{*}{$\begin{array}{c}\text { Pengeta } \\
\text { huan }\end{array}$} & \multicolumn{4}{|c|}{ Pengguna Jamban } & \multicolumn{2}{|c|}{ Total } & $\mathrm{P}$ \\
\hline & $\begin{array}{c}\text { Menggu } \\
\text { nakan }\end{array}$ & $\%$ & $\begin{array}{c}\text { Tidak } \\
\text { menggu } \\
\text { nakan }\end{array}$ & $\%$ & $\mathrm{n}$ & $\%$ & \multirow[t]{4}{*}{$\begin{array}{c}0,0 \\
01\end{array}$} \\
\hline Baik & 80 & $\begin{array}{c}82, \\
4\end{array}$ & 13 & $\begin{array}{r}13 \\
4\end{array}$ & $\begin{array}{l}9 \\
3\end{array}$ & $\begin{array}{c}95 \\
, 8\end{array}$ & \\
\hline Kurang & 1 & $\begin{array}{c}1,1 \\
\%\end{array}$ & 3 & $\begin{array}{c}3, \\
1\end{array}$ & 4 & $\begin{array}{l}4, \\
2\end{array}$ & \\
\hline Total & 84 & & 16 & & $\begin{array}{l}9 \\
7\end{array}$ & $\begin{array}{c}10 \\
0\end{array}$ & \\
\hline
\end{tabular}

Sumber: Olah data, 2020

Dari tabe 4.7 di atas terlihat bahwa tabulasi silang yang menampilkan informasi hubungan anatara variabel pengetahuan dengan variabel Penggunaan Jamban di Ruang Poli Klinik Rumah Sakit Umum Daerah Polewali Mandar dimana ada 80 responden (82,4\%) yang pengetahuaanya baik menggunakan jamban, dan 1 responden (1,1\%) yang pengetahuannya kurang menggunakan jamban, dan 13 responden (13,4\%) yang pengetahuannya baik tidak menggunakan jamban, dan 3 $(3,1 \%)$ yang berpengetahuan kurang tidak menggunakan jamban. Berdasarkan tabel chy squere terlihat nilai $\mathrm{P}$ value sebesar 0.001, maka sesuatu dasar keputusan chy squere dapat disimpulkan ho ditolak dan ha diterima yang mana berarti bahwa semakin bagus pengetahuan seseorang maka akan meningkat sikap mereka dalam pemanfaatan jamban yang baik di Ruang Poli Klinik Rumah Sakit Umum Daerah Polewali Mandar.

\section{b) Hubungan Kontruksi Jamban dan Penggunaan Jamban}

Tabel 4.8 Kategori dan Distribusi Frekuensi Hubungan Kontruksi Jamban dengan Penggunaan Jamban di Ruang Poli Klinik Rumah Sakit Umum Daerah Polewali Mandar

\begin{tabular}{|c|c|c|c|c|c|c|c|}
\hline \multirow{2}{*}{$\begin{array}{c}\text { Kontr } \\
\text { uksi } \\
\text { Jamba } \\
\text { n }\end{array}$} & \multicolumn{4}{|c|}{ Pengguna Jamban } & \multicolumn{2}{|c|}{ Total } & $P$ \\
\hline & $\begin{array}{c}\text { Menggu } \\
\text { nakan }\end{array}$ & $\%$ & $\begin{array}{c}\text { Tidak } \\
\text { meng } \\
\text { guna } \\
\text { kan }\end{array}$ & $\%$ & $\mathrm{n}$ & $\%$ & \multirow[t]{4}{*}{0,040} \\
\hline $\begin{array}{l}\text { Meme } \\
\text { nuhi } \\
\text { Syarat }\end{array}$ & 68 & $\begin{array}{l}70 \\
\%\end{array}$ & 10 & $\begin{array}{c}10 \\
, 3\end{array}$ & 78 & $\begin{array}{l}83 \\
, 5 \\
\% \\
\end{array}$ & \\
\hline $\begin{array}{c}\text { Tidak } \\
\text { Meme } \\
\text { nuhi }\end{array}$ & 13 & $\begin{array}{l}13 \\
, 5\end{array}$ & 6 & $\begin{array}{c}6, \\
18\end{array}$ & 19 & $\begin{array}{l}19 \\
, 5 \\
\% \\
\end{array}$ & \\
\hline Total & 84 & & 16 & & 97 & $\begin{array}{c}10 \\
0\end{array}$ & \\
\hline
\end{tabular}

Dari output diatas terlihat tabulasi silang yang memuat informasi hubungan antara variabel Kontruksi Jamban dengan variabel Penggunaan Jamban di Ruang Poli Klinik RS UMUM Polewali Mandar dimana ada 68 responden (70\%) yang mengatakan kontruksi jamban memenuhi syarat dan tidak menggunakan jamban, dan 13 responden (13,5\%) yang memenuhi syarat dan menggunakan jamban. Selengkapnya bisa diperhatikan pada tabel diatas.

Dari hasil output chy squere (Lihat lampiran) terlihat nilai $\mathrm{P}$ value senilai $0.040<0.05$, Oleh karena itu, sesuai dengan dasar membuat keputusan, dapat disimpulkan jika HA diterima dan Ho ditolak. Dengan demikian dapat disimpulkan bahwa Kontruksi jamban yang memenuhi syarat akan meningkatkan penggunaan jamban di Ruang Poli Klinik Rumah Sakit Umum Daerah Polewali Mandar.
c) Hubungan Kebersihan Jamban dan Penggunaan Jamban

Tabel 4.9 Kategori dan Distribusi Frekuensi Hubungan Kebersihan Jamban dengan Penggunaan Jamban di Ruang Poli Klinik Rumah Sakit Umum Daerah Polewali Mandar

\begin{tabular}{|c|c|c|c|c|c|c|c|}
\hline \multirow{2}{*}{$\begin{array}{c}\text { Kontruksi } \\
\text { Jamban }\end{array}$} & \multicolumn{4}{|c|}{ Pengguna Jamban } & \multicolumn{2}{|c|}{ Total } & $\mathrm{P}$ \\
\hline & $\begin{array}{l}\mathrm{Me} \\
\text { ngg } \\
\text { una } \\
\text { kan }\end{array}$ & $\%$ & $\begin{array}{c}\text { Tidak } \\
\text { menggu } \\
\text { nakan }\end{array}$ & $\%$ & $\mathrm{~N}$ & $\%$ & $\begin{array}{l}0,0 \\
29\end{array}$ \\
\hline $\begin{array}{c}\text { Memenuhi } \\
\text { Syarat }\end{array}$ & 75 & $\begin{array}{l}77, \\
3 \%\end{array}$ & 12 & $\begin{array}{l}12 \\
, 3\end{array}$ & 87 & $\begin{array}{l}92 \\
, 7 \\
\%\end{array}$ & \\
\hline $\begin{array}{c}\text { Tidak } \\
\text { Memenuhi }\end{array}$ & 6 & $\begin{array}{c}6,1 \\
\%\end{array}$ & 4 & $\begin{array}{c}4 \\
1\end{array}$ & 10 & $\begin{array}{l}10 \\
, 3 \\
\%\end{array}$ & \\
\hline Total & 84 & & 16 & & 97 & & \\
\hline
\end{tabular}

Dari output diatas terlihat tabulasi silang yang memuat informasi hubungan antara variabel Kebersihan Jamban dengan variabel Penggunaan Jamban di Ruang Poli Klinik Rumah Sakit Umum Daerah Polewali Mandar dimana ada $75(77,3 \%)$ responden yang menggunakan jamban dan mengatakan kebersihan jamban memenuhi syarat, serta ada $6(6,1 \%)$ yang memenuhi syarat dan menggunakan jamban. Selengkapnya bisa diperhatikan pada tabel diatas.

Berdasarkan tabel chy squere terlihat nilai $\mathrm{P}$ value sebesar 0.029, maka sesuatu dasar keputusan chy squere dapat disimpulkan ho ditolak dan ha diterima yang mana berarti bahwa bahwa Kebersihan jamban akan meningkatkan penggunaan jamban di Ruang Poli Klinik RS UMUM Polewali Mandar.

\section{d) Hubungan Kebersihan Jamban dan Penggunaan Jamban}

Tabel 4.10 Kategori dan Distribusi Frekuensi Hubungan Ketersediaan Air Bersih Dengan Penggunaan Jamban di Ruang Poli Klinik Rumah Sakit Umum Daerah Polewali Mandar 


\begin{tabular}{|c|c|c|c|c|c|}
\hline \multirow{2}{*}{$\begin{array}{c}\text { Ketersedi } \\
\text { aan Air } \\
\text { Bersih }\end{array}$} & \multicolumn{2}{|c|}{$\begin{array}{c}\text { Penggunaan } \\
\text { Jamban }\end{array}$} & \multirow[b]{2}{*}{ Total } & \multirow[b]{2}{*}{$\%$} & \multirow[b]{2}{*}{$\mathrm{P}$} \\
\hline & $\begin{array}{l}\text { Meng } \\
\text { guna } \\
\text { kan }\end{array}$ & $\begin{array}{l}\text { Tidak } \\
\text { menggun } \\
\text { akan }\end{array}$ & & & \\
\hline $\begin{array}{l}\text { Memenu } \\
\text { hi Syarat }\end{array}$ & 78 & 12 & 93 & 95,8 & \multirow{3}{*}{0,002} \\
\hline $\begin{array}{c}\text { Tidak } \\
\text { Memenu } \\
\text { hi }\end{array}$ & 3 & 4 & 7 & 7,2 & \\
\hline Total & 84 & 16 & 97 & 100 & \\
\hline
\end{tabular}

Dari tabe 4.10 di atas terlihat bahwa tabulasi silang yang menampilkan informasi hubungan anatara variabel air bersih dengan variabel Penggunaan Jamban di Ruang Poli Klinik Rumah Sakit Umum Daerah Polewali Mandar dimana ada 78 responden atau 80,4\% yang menggunakan jamban mengatakan kebersihan jamban memenuhi syarat, dan ada 3 yang memenuhi syarat dan menggunakan jamban atau $3,1 \%$. Selengkapnya bisa diperhatikan pada tabel diatas.

Berdasarkan tabel output chy squere (Lihat lampiran) menunjukkan nilai $\mathrm{P}$ value sebesar 0.002 Berdasarkan tabel chy squere terlihat nilai $\mathrm{P}$ value sebesar 0.001 , maka sesuatu dasar keputusan chy squere dapat disimpulkan Ho ditolak dan ha diterima yang mana berarti bahwa bahwa Ketersediaan Air Bersih akan meningkatkan penggunaan jamban di Ruang Poli Klinik Rumah Sakit Umum Daerah Polewali Mandar.

\section{Pembahasan}

Dari output diatas terlihat tabulasi silang yang memuat informasi hubungan antara variabel Kebersihan Jamban dengan variabel kebersihan Jamban di Ruang Poli Klinik Rumah Sakit Umum Daerah Polewali Mandar dimana ada 75 (77,3\%) yang mengatakan bersih dan mengatakan kebersihan kurang bersih, serta ada 6 $(6,1 \%)$ yang memenuhi syarat dan menggunakan jamban. Selengkapnya bisa diperhatikan pada tabel diatas.

Berdasarkan tabel output chy squere (Lihat lampiran) menunjukkan nilai $\mathrm{P}$ value sebesar 0.029 karena nilai $\mathrm{P}<0,05$, maka berdasarkan dasar pengambilan keputusan, dapat disimpulkan bahwa Ho ditolak dan $\mathrm{Ha}$ diterima. Dengan demikian dapat diartikan bahwa Kebersihan jamban akan meningkatkan penggunaan jamban di Ruang Poli Klinik Rumah Sakit Umum Daerah Polewali Mandar.

\section{SIMPULAN}

Dari hasil penelitian yang dilakukan pada Ruang poli klinik RS umum Daerah Polewali Mandar yang berjumlah 97 responden diperoleh kesimpulan bahwa:

1. Ada Hubungan Faktor Pengetahuan dengan Penggunaan Jamban di Ruang Poli Klinik Rumah Sakit Umum Daerah Polewali Mandar dimana nilai P $0,01<0,05$.

2. Ada Hubungan Faktor Kontruksi Jamban dengan Penggunaan Jamban di Ruang Poli Klinik Rumah
Sakit Umum Daerah Polewali Mandar dimana nilai $\mathrm{P} 0,040<0,05$

3. Ada Hubungan Faktor Sanitasi Jamban dengan Penggunaan Jamban di Ruang Poli Klinik Rumah Sakit Umum Daerah Polewali Mandar dimana nilai $\mathrm{P} 0,029<0,05$.

4. Ada Hubungan Faktor Ketersediaan Air Bersih dengan Penggunaan Jamban di Ruang Poli Klinik Rumah Sakit Umum Daerah Polewali Mandar dimana nilai $\mathrm{P} 0,002<0,05$.

\section{DAFTAR PUSTAKA}

Alamsya \& ratna. 2013 Pilah dasar ilmu kesehatan. Yogyakarta: Medika.

Anonym. 2016. Sisitem Pengolahan Air Limbah.

Azrul, Anwar, 2016. Pengantar Ilmu Kesehatan Lingkungan. PT. Mutiara Sumbar Widjaya. Jakarta.

Azwar. 2015. Faktor Pembentukan sikap. Rineka cipta: Jakarta.

Depkes. RI, Tahun 2017. Profi Kesehatan Provinsi Sulawesi Tenggara

Depkes. RI. Tahun 2017. Petunjuk Pelaksanaan Pembangunan Sarana PABL.

Dinkes, 18 APRIL 2016.Menggunakan Jamban Sehat

Entjang. 2015. pengertian septictan. Rineka Cipta. Jakarta.

Http://www.depke.gpidi

artkel/view/181818181881/program Indonesia sehat dengan pendekatan keluarga.html. diakses 28 mei 2019.

Kementrian kesehatan, 2017. Program Indonesia sehat. Artikel.

Kementrian Perencanaan Pembangunan Nasional/Badan Perencanaan.

Kusnoputranto, Haryoto, 2016. Kesehatan Lingkungan. Fakultas Kesehatan Masyarakat. Universitas Indonesia.

Muthmaina. 2016. Pengetahuan serta tindakan penduduk dalam memanfaatkan jamban keluarga. Rineka cipta.Jakarta.

Notoatmojo, Soekidjo, 2017.Pengantar Metodelogi Penelitian Kesehatan. Rineka Cipta. Jakarta.

Pangade Sukardi, Yusrianto.2013. Panduan Penulisan Skripsi. Indomedia. Makassar.

Pembangunan Nasional (BAPPENAS), 2010.Buku I Prioritas Nasional. Jakarta

Permenkes 7. Tahun 2019. Tentang Kesehatan Lingkungan Rumah Sakit

Rahma, A. S. N., Sukmawati, S., \& Liliandriani, A. (2019, November). Gambaran Kondisi Sanitasi Kolam Renang di Waterboom. In Journal 
Peqguruang: Conference Series (Vol. 1, No. 2, pp. 246-251).

Soemadji, Josep, 2015. Pembuangan Kotoran dan Air Limbah.Proyek Pengembangan Pendidikan Tenaga Sanitasi Pusat. Jakata.

Umar, Alimin H.M, 2016. Aspek Kesehatan Pengelolaan Ekstreta Manusia\& Air Limbah. FKM-UNHAS. Ujungpandang.

Umar, Alimin H.M, 2016. Pengaruh Kualitas Sanitasi Lingkungan Terhadap Pola Penyakit Masyarakat Daerah Pantai. LP-UNHAS. Ujung pandang.

Undang-Undang Repoblik Indonesia No. 23 Tahun 1992. Tentang Kesehatan. Jakarta.

World Healt Organization.2016. Healt Principte of Housing. Geneva. 